\title{
Understory vegetation as environmental factors indicator in forest ecosystems
}

\author{
${ }^{1 *}$ A. Mataji; ${ }^{2}$ P. Moarefvand; ${ }^{1}$ S. Babaie Kafaki; ${ }^{1}$ M. Madanipour Kermanshahi \\ ${ }^{1}$ Department of Forestry, Science and Research Branch, Islamic Azad University, Tehran, Iran \\ ${ }^{2}$ Department of Mining and Metallurgy Engineering, Amirkabir University, Tehran, Iran
}

Received 14 December 2009; $\quad$ revised 26 May 2010; $\quad$ accepted 8 July 2010

\begin{abstract}
Physiographic factors along with edaphic conditions play a crucial role in establishment of plant species throughout a region. Identification of the most effective factors is of high importance in sustainable management of a forest ecosystem. This study aims to investigate the relationships between understory vegetation and some environmental factors in natural forest ecosystems. This study has been carried out among the Fagetum orientalis communities of Ramsar Region, located in the north of Iran. For this purpose, 105 releves were sampled by a randomizedsystematic method throughout the study area, using the Braun-Blanquet scale. Physiographic parameters such as elevation, as well as slope and orientation were measured. By identification of the herb-layer vegetation contained in each sampling, vegetation composition and cover abundance of species were separately identified. Then, the aforementioned properties of soil were entirely measured in the taken samples. Cluster analysis and detrended correspondence analysis have been applied to classify the site. Moreover, in order to determine the relation between species composition and environmental factors, canonical correspondence analysis was used. Results showed a significant relation between distribution of plant types and environmental factors. Eventually, environmental factors including slope, orientation, silt percent, $\mathrm{pH}$, organic matter and soluble phosphorous were among the most effective factors in establishment of Hedera pastuchowii, Solanum kieseritzkii, Oplismenus undulatifolius, Sedum stoloniferum, Rubus hyrcanus and Saxifraga cymbalaria species.
\end{abstract}

Keywords: Environmental factors; Herb. layer; Multivariate analysis

\section{INTRODUCTION}

One of the main objectives of silvicultural management is the sustainable utilization of natural resources, often strived for through close-to-nature forestry. However, to support the socio-economic functions of the forest ecosystem, the conservation of stable and productive forests with diverse tree species must be ensured (Mölder et al., 2006; 2008). The effects of environmental variables on plant communities have been the subject of many ecological studies in recent years (Pinto et al., 2006; Naqinezhad et al. 2008; Ramirez et al., 2007; Mahmood and Athar, 2008; Lepetu et al., 2009; Kord et al., 2010). Effective and appropriate management of natural resources cannot be provided without a comprehensive scientific recognition. Therefore, ecological study of present resources, as

*Corresponding Author Email: amataji@srbiau.ac.ir Tel./Fax: +9821 44861784 well as the environment can establish a proper equilibrium between forest production and logging (Gueu et al., 2007; Igwe et al., 2008; Mataji et al., 2009). As plant coverage exposes different environmental factors such as microclimate, soil, light and physiographic properties, the direct measurement of these factors needs a costly plan (Daubenmire, 1976). To overcome this issue at low cost and within a short time, determination of ecological groups throughout a region is applied (Meilleur and Bergeron, 1992). In other words, plants reflex a complex of environmental properties, including climate and soil variables (Ellenberg, 1992). By direct identification of plant communities, it is strongly possible to detect the dominant conditions on the forest, plant species with similar ecological needs, as well as the plant community itself (Hassanzad Navroodi et al., 2004). Identification 
of homogenous sites according to the plant coverage involves a highly attentive process which eases the further studies (Spies and Barnes, 1985; Pourhashemi et al., 2004). Ordination and classification are effective techniques for multivariate analyses of community structure in vegetation ecology (Zhang et al., 2008). Plant communities are separated from each other based on indicator species in combination with a distinctive floristic composition (Eshaghi-Rad et al., 2009). Upon the recent studies, soil variables are among the most important factors of site in classification of plant communities (Archambault et al., 1989; Zahedi Amiri and Mohammadi Limayi, 2002). The herb-layer vegetation grown throughout the ground of the forests have a short lifetime and fewer changes towards the environmental factors; therefore, they normally report more logical results in classification of forest site especially during the high condition varieties (Schmidt, 2005; BernhardtRömermann et al., 2007; Karimzadegan et al., 2007). Herb-layer vegetation contributes significantly to ecosystem functioning in forests (Augusto et al., 2003). Moreover, tree and herb layers are favoured in silviculture, as long as herb-layer vegetation does not compete with tree regeneration for light, water and nutrients (Morris et al., 1993; Coll et al., 2003).

Hence, according to the importance of aforementioned items, this study aims to provide the following goals using study of herb-layer vegetation and edaphic conditions:

- The most crucial soil factors and site parameters are identified using investigation of the relationship of herb-layer vegetation and physiographic and edaphic conditions.

- The species with similar ecological needs are identified.

\section{MATERIALS AND METHODS}

Study area

This study has been carried out throughout the beech (Fagus orientalis Lipsky) communities located along the northern facing slops of Ramsar forest (Fig. 1), at an altitude of 1000-1300 $\mathrm{m}$ a.s.l., in the north of Iran (36 49’26" N latitude and 59 $30^{\prime} 28^{\prime \prime}$ E longitudes). The dominant soil type of the area is acidic and forest brown classified within the Dystrochrepts groups. Average annual precipitation is $1200 \mathrm{~mm}$ and the mean annual temperature is estimated to be $15{ }^{\circ} \mathrm{C}$ (Samghabodi et al., 2004). Fagetum hyrcanum has been detected as the dominant community and Fagus orientalis, Alnus subcordata, Carpinus betulus, Geum urbanum, Asperula odorata are the most frequent tree and herb-layer species.

\section{Sampling and analysis of data \\ Herb-layer vegetation}

In order to sample the plant coverage using the minimal area method in the recent study was identified (Mataji et al., 2007) and 105 releves were sampled using a randomized-systematic method. Firstly, physiographic parameters such as elevation, as well as slope and orientation were measured by means of Altimeter and clinometers, respectively. Then, by identification of the herb-layer vegetations contained in each sampling, presence percent of species were separately identified. Geographic orientation was quantified by the following correlation to be applied in multivariable analysis (Fu et al., 2004):

$A^{\prime}=(\operatorname{Cos}(45-A)+1)$

Where, A is the azimut amount of the orientation. Also, for identification and classification of vegetation cover, the method of Braun-Blanquet (1932) combined abundance-cover scale was used.

\section{Soil}

Due to a mutual relation between the plant communities and soil properties, the whole samples were taken of $0-30 \mathrm{~cm}$ depth (below the organic layers).soil properties, including texture, $\mathrm{pH}$, soluble calcium, soluble magnesium, total nitrogen, phosphorous, soluble sodium, soluble potassium and organic matters were measured in laboratory. The aforementioned properties were respectively measured by hydrometer method, $\mathrm{pH}$ meter, Titration with soluble EDTA method, Kjeldahl method, Olsson method, flame photometry and finally Walkley-Black method.

\section{Statistical analysis}

Cluster analysis was applied to determine the ecological groups. This is a collective classification method which initially measures the distance matrices between the sampling plots, then select and compound two groups among the tested groups. Sorenson method and Flexible beta have been applied to measure the 


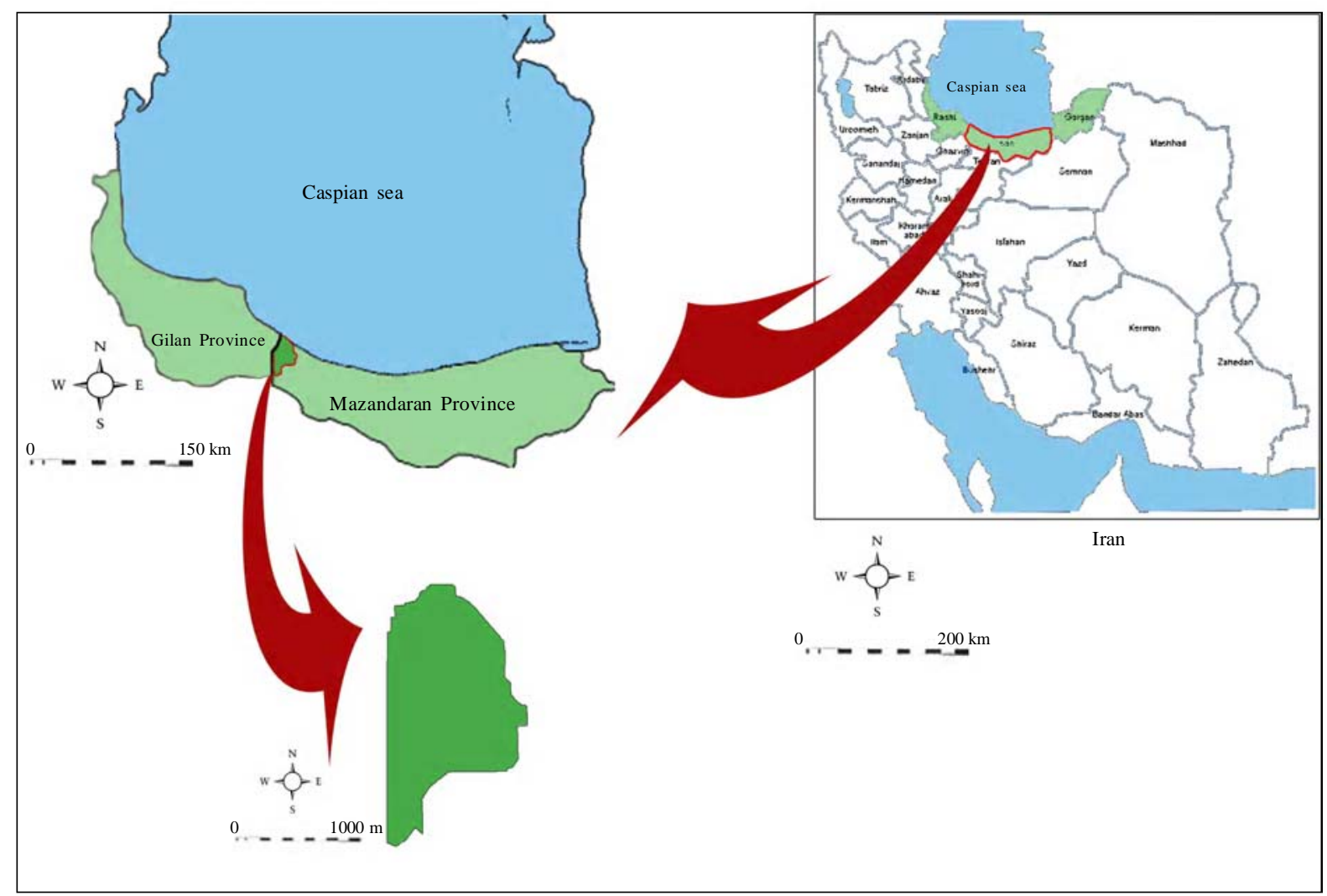

Fig. 1: Location of the study area

distance between the sampled species and combination of the groups, respectively. In order to select the optimized number of clusters, Indicator species analysis was applied. Sample plots were also ordinated based on species composition and abundance using detrended correspondence analysis (DCA), (Hill and Gauch, 1980). The relationship of plant coverage and measured environmental variables were then identified by canonical correspondence analysis (CCA). In this manner, the location of the taken samples was measured towards the variables in a coordinate system and using a factorial system (Hassani Pak and Sharafodin, 2005). In other words, this method shows simultaneously the environmental variables and distribution of plant species (Ter-Braak, 1986). The length of vector in each axis reports the correlation between the axis and the related variables. The longer the vector, the higher is the correlation level. Using the KolmogorovSmirnov test, the normalization of the variable distribution is investigated. Multivariate analysis of the species is also performed by PC-ORD version
4.14 (McCune and Mefford, 1999). In addition, SPSS, version 12.0 is applied to study the correlation between the variables.

\section{RESULTS AND DISCUSSION}

Using cluster analysis, forest ecosystem was classified into different groups. Dendrogram of the cluster analysis is shown in Fig 2. The samples with similar floristic composition were arranged beside and separated from other sampling parts. The results showed that 3 clusters are greatly suitable for analysis. Figs. 3 and 4 show the ordination results of the detrended correspondence analysis of all sampling plots in the first 3 axis. As shown in the same Figs, sampling plots of first group are located in the negative part of the first axis of diagram, whereas the second group is placed in the positive part. This is mainly due to the difference in site conditions of the aforementioned groups. The highest evaluation reported for $11^{\text {th. }}$ and $24^{\text {th. }}$ sampling plots contained in $1^{\text {st. }}$ and $2^{\text {nd. }}$ groups, respectively. The both mentioned 
Understory vegetation in forest ecosystems

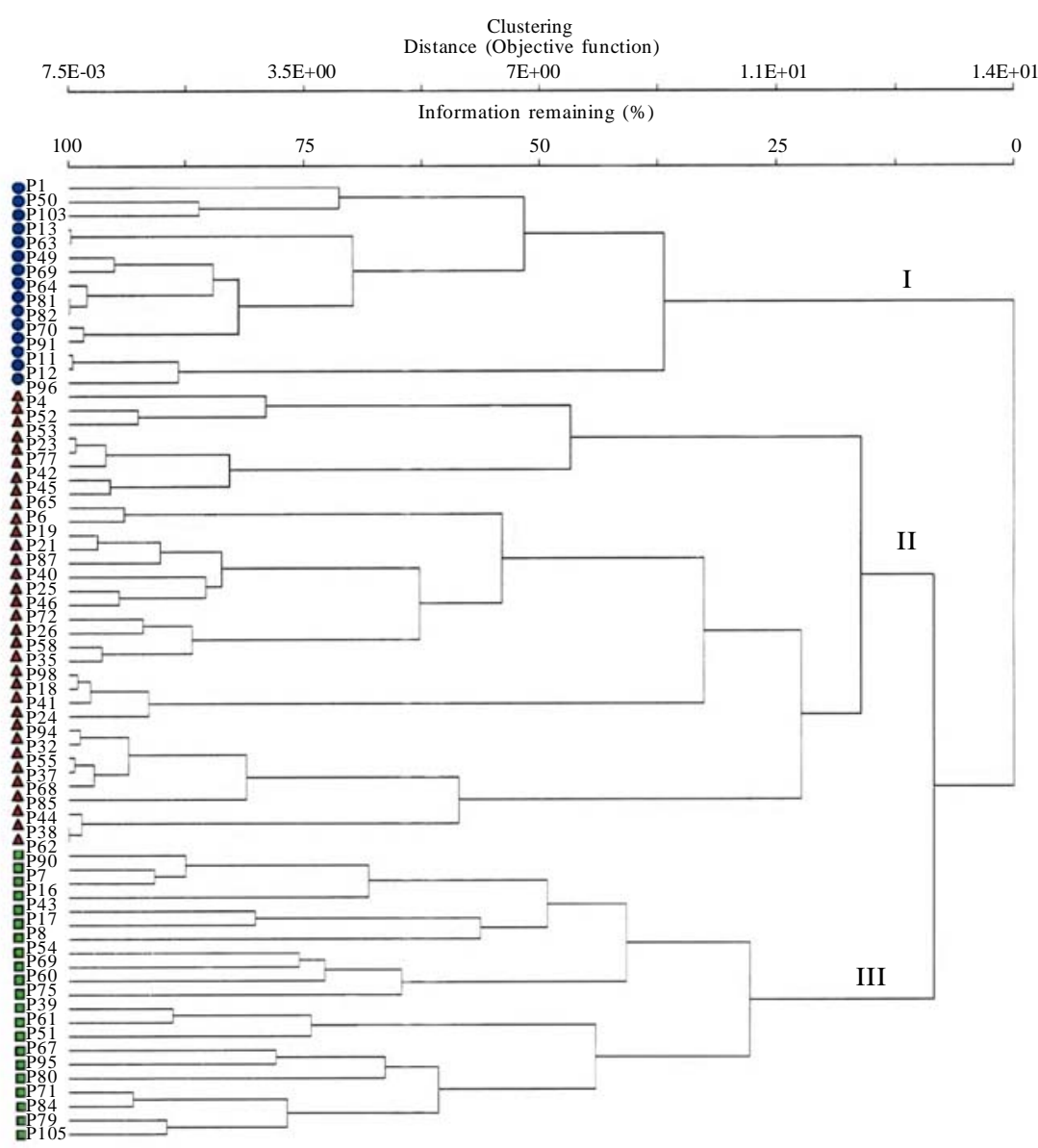

Fig. 2: Dendrogram of cluster analysis of the herb-layer vegetation in the study area

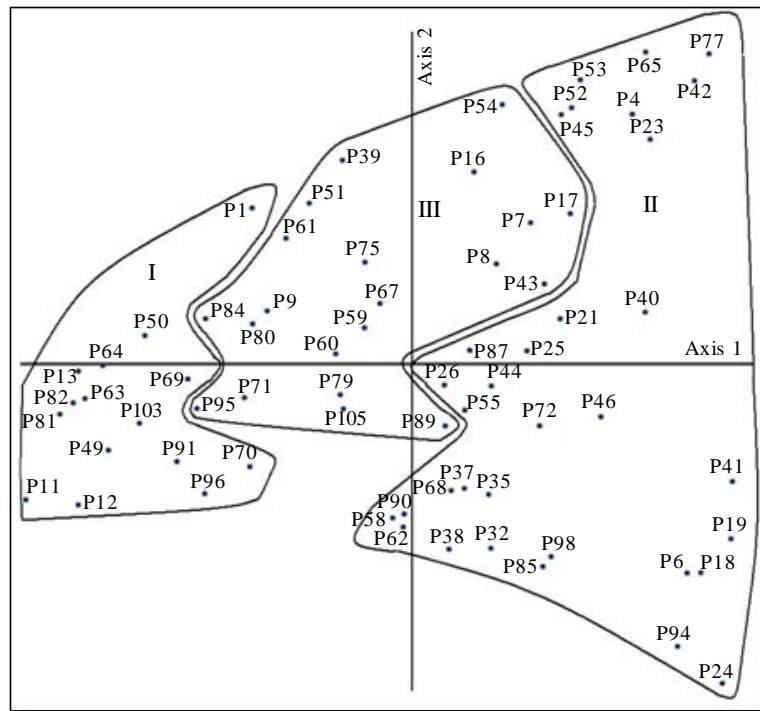

Fig. 3: First two DCA ordination axes obtained based on all plots 


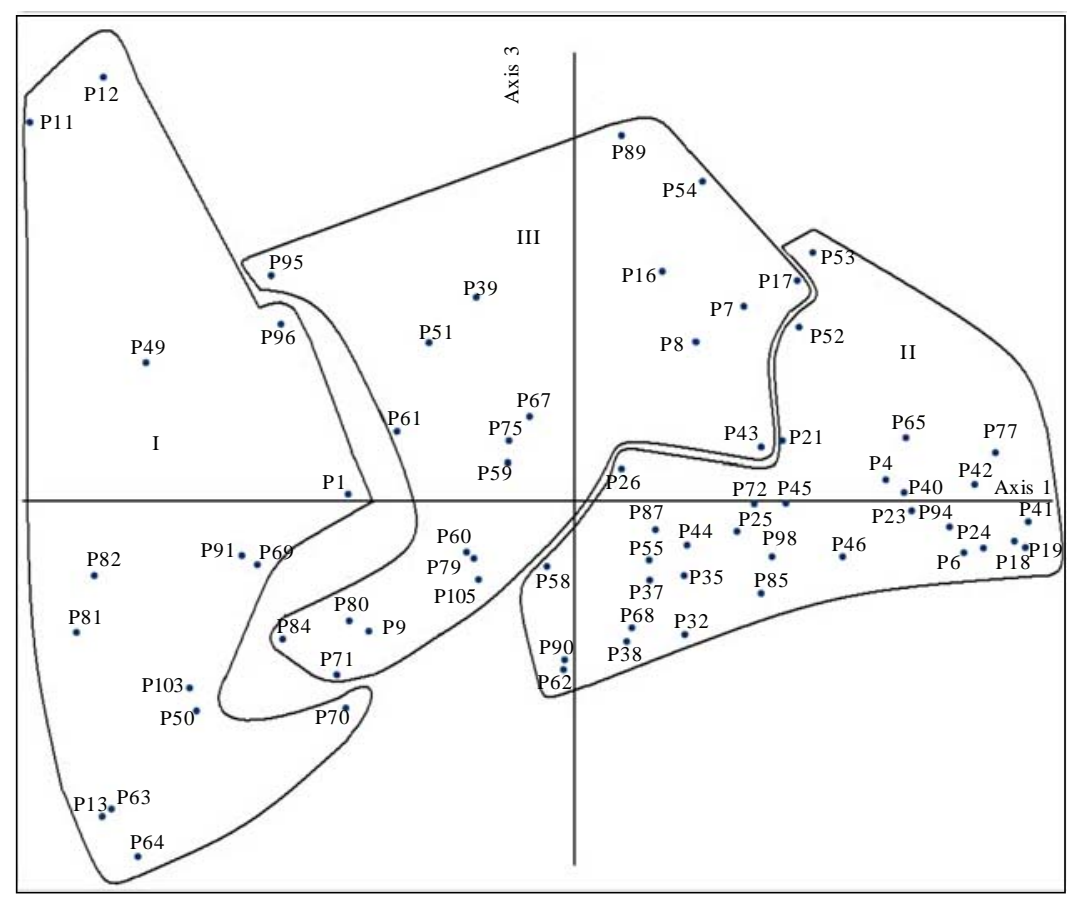

Fig. 4: DCA ordination axes obtained based on sampling plots in first and third axis

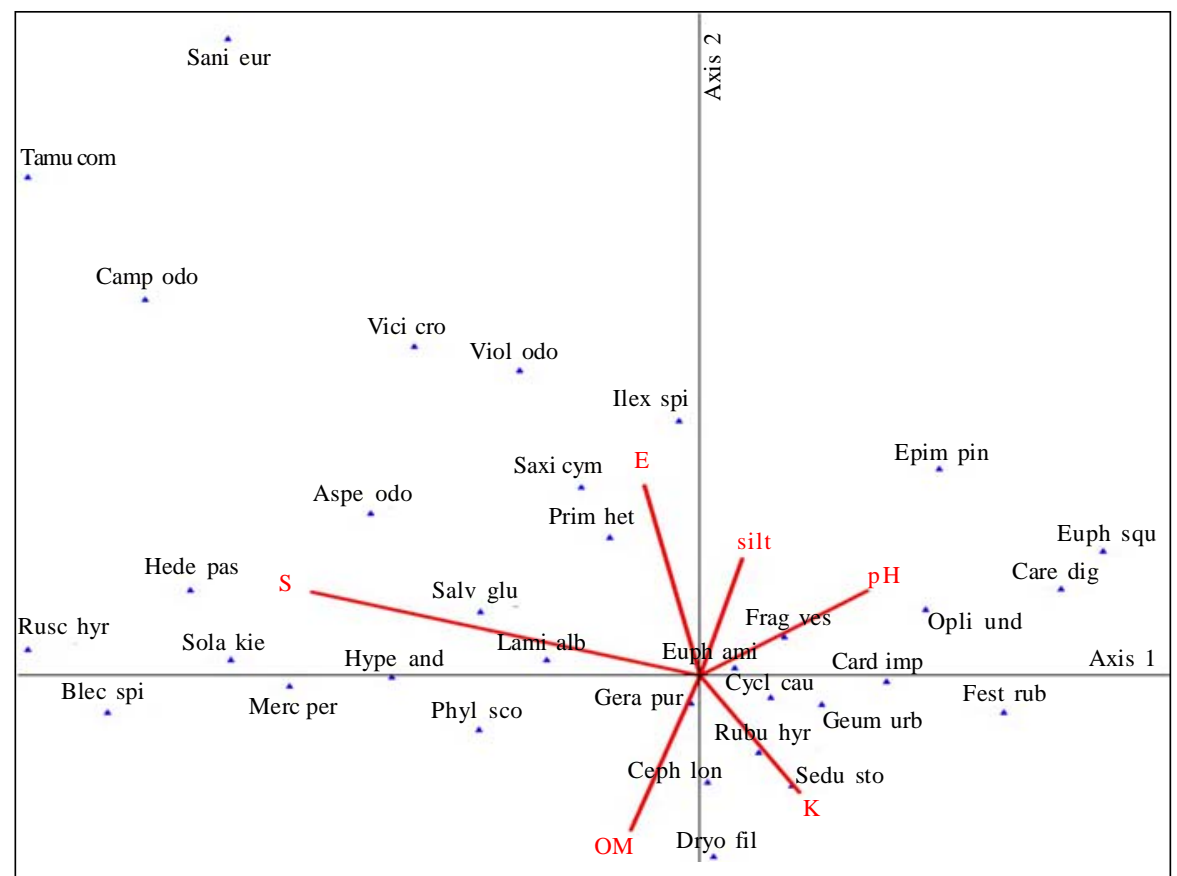

Fig. 5: Classification diagram of the canonical correspondence analysis of herb-layer vegetation, as well as the most important physiographic and soil factors (soluble potassium (K), organic matter (OM), slope (s), elevation from sea level $(\mathrm{E})$, silt percent and $\mathrm{pH})$ in $1^{\text {st. }}$ and $2^{\text {nd. }}$ axis 
sampling plots are the particular definer of two groups (1 and 2) with entirely different edaphic and environmental conditions. Moreover, sampling plots of third group located in the central part of coordinate axis inclined towards the positive sections of the second and third axis.

Canonical correspondence analysis is applied in order to investigate the relation of environmental factors and plant coverage. Eigenvalue of 3 axes were $0.27,0.19$ and 0.13 , respectively. The first axis has shown the positive (0.296) and negative (- 0.69) correlation with $\mathrm{pH}$ and slope factors, respectively. Second axis had a relatively high positive correlation with elevation factor. In contrary, the same axis showed a negative correlation with organic matters. However, the same positive and negative correlation has been reported between soluble potassium and silt content in the soil with second axis, respectively (Fig. 5 and Table 1). Fig. 5 reveals that the establishment of Hedera pastuchowii, Solanum kiesereritzkii located in the negative parts of the first axis were mainly affected by region slope and tends to the high slope grounds. Oplismenus undulatifolius, Epimedium pinnatum and Fragaria vesca in the positive section of the $1^{\text {st }}$ axis were located in the soils with higher pH levels. Potassium content in soil is considered as the most substantial factor in the presence of Sedum stoloniferum and Rubus hyrcanus. However, elevation from the sea surface was reported as the crucial factor in the growth of Saxifraga cymbalaria and Primula heterochroma. Dryopteris filix-mas and Cephalantera longifolia were observed in the forth quarter in the orientation of soluble potassium (K) and organic material (OM) axes (Fig. 5).

Among the soil properties, soluble phosphorous had the highest correlation with the negative part of the third axis. Also, it was reported to have a high and low negative value in the third and first axis, respectively for Cephalantera longifolia located in the forth quarter.

In general, the species grown within the $1^{\text {st. }}, 3^{\text {rd. }}, 4^{\text {th. }}$ quarters are substantially affected by physical as well as chemical factors. However, the physiographic factors affect on the second quarter species (Figs. 5, 6). Results of Pearson Test demonstrated that $\mathrm{pH}$ of soil has a negative correlation with soluble potassium, sand percent and altitude factors and a high positive correlation with silt percent. A significant correlation

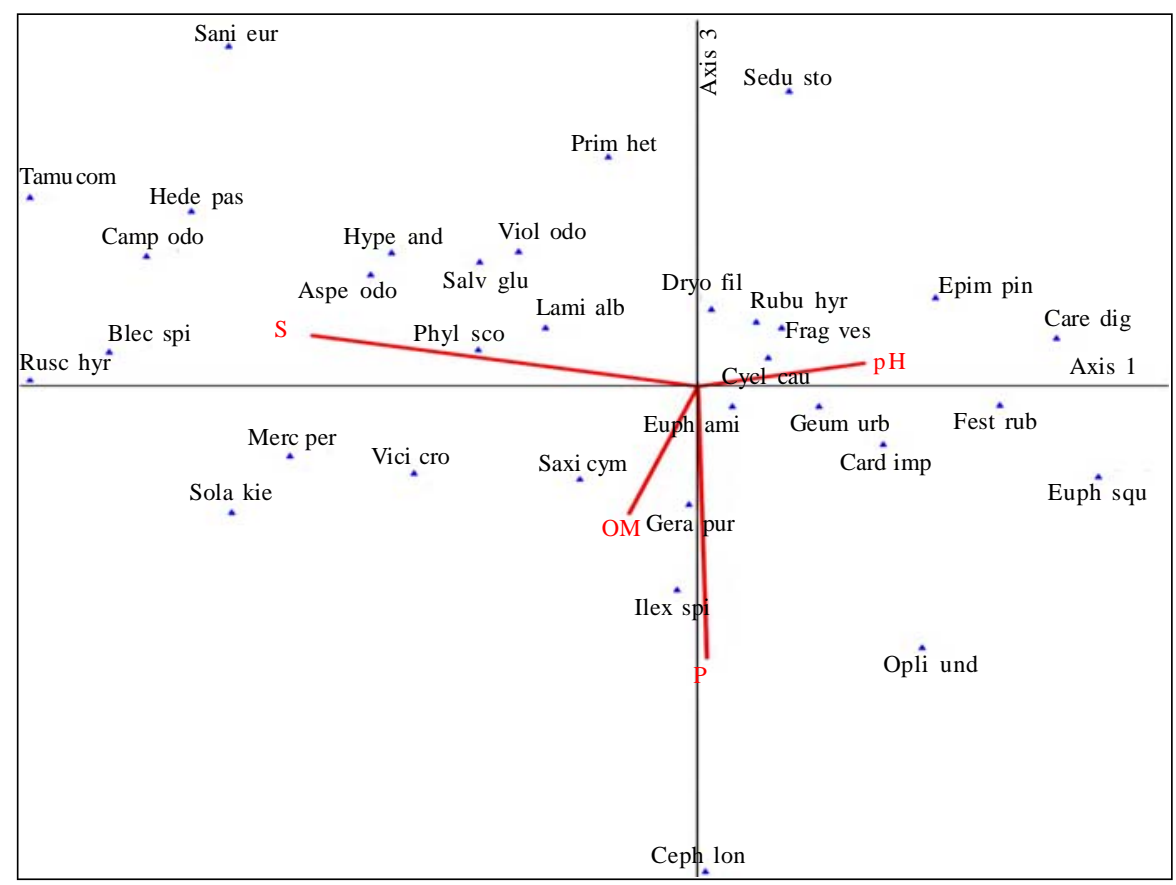

Fig 6: Classification diagram of the canonical correspondence analysis of herb-layer vegetation, as well as the most important physiographic and soil factors (soluble phosphorous (P), organic matter $(\mathrm{OM})$, slope $(\mathrm{S})$ and $\mathrm{pH})$ in the first and third axis 
Int. J. Environ. Sci. Tech., 7 (4), 629-638, Autumn 2010

Table 1: Correlation ratio in 3 axes and the Pearson correlation ratio between the environmental variables and soil properties

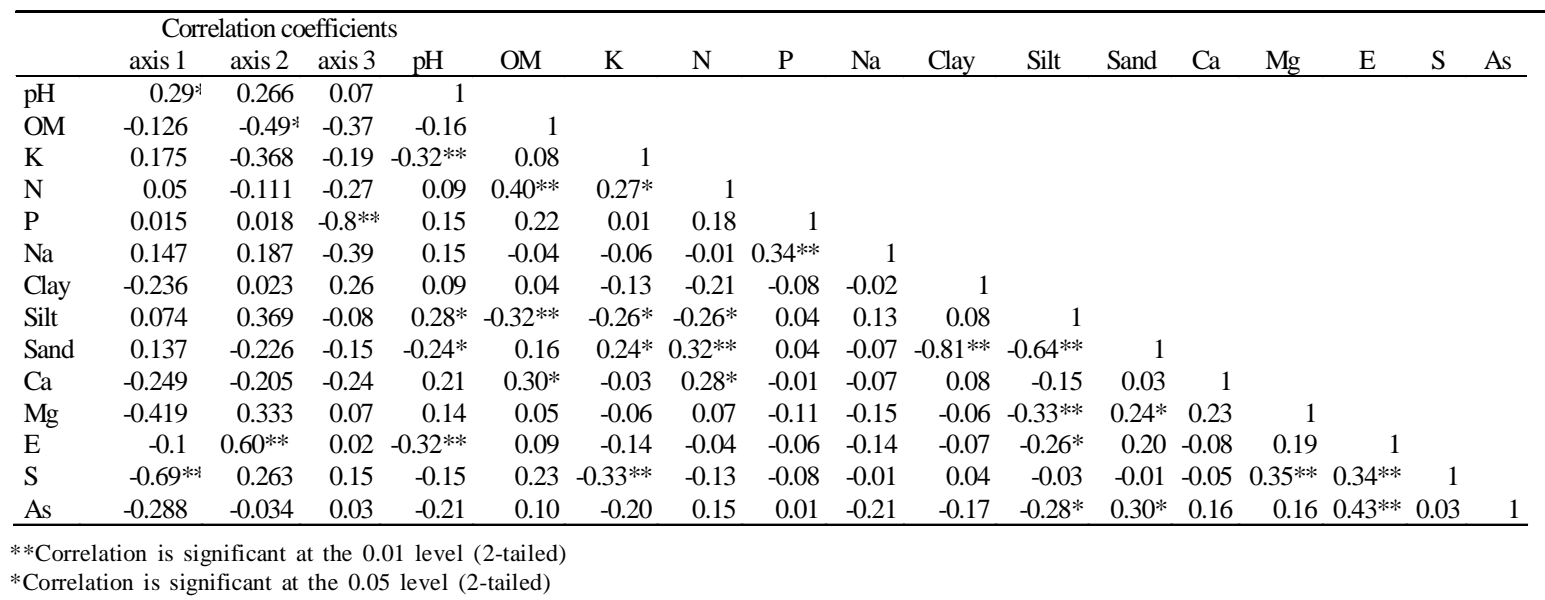

Table 2: Correlation between herb-layer species and environmental variables

\begin{tabular}{|c|c|c|c|c|c|c|c|c|c|c|}
\hline & & $\begin{array}{c}\text { Carex } \\
\text { digidata } \\
\end{array}$ & $\begin{array}{l}\text { Sanicula } \\
\text { europea }\end{array}$ & $\begin{array}{l}\text { Epimedium } \\
\text { pinnatum }\end{array}$ & $\begin{array}{c}\text { Viola } \\
\text { odorata }\end{array}$ & $\begin{array}{c}\text { Tamus } \\
\text { communis }\end{array}$ & $\begin{array}{c}\text { Cruciata } \\
\text { taurica }\end{array}$ & $\begin{array}{c}\text { Fragaria } \\
\text { vesca }\end{array}$ & $\begin{array}{c}\text { Cephalantera } \\
\text { longifolia }\end{array}$ & $\begin{array}{c}\text { Oplismenus } \\
\text { undulatifolius }\end{array}$ \\
\hline \multirow[t]{2}{*}{$\mathrm{pH}$} & Pearson Correlation & 0.165 & $0.282 *$ & $0.32^{* *}$ & 0.23 & $0.244^{*}$ & $0.301^{*}$ & $0.24 *$ & 0.196 & 0.19 \\
\hline & Sig.(2-tailed) & 0.177 & 0.019 & 0.09 & 0.057 & 0.044 & 0.012 & 0.05 & 0.106 & 0.12 \\
\hline \multirow[t]{2}{*}{$\mathrm{OM}$} & Pearson Correlation & -0.104 & -0.23 & -0.03 & $-0.297 *$ & -0.196 & $-0.292 *$ & -0.02 & 0.118 & 0.10 \\
\hline & Sig.(2-tailed) & 0.394 & 0.057 & 0.8 & 0.013 & 0.106 & 0.015 & 0.91 & 0.333 & 0.41 \\
\hline \multirow[t]{2}{*}{$\mathrm{K}$} & Pearson Correlation & 0.066 & $-0.378 * *$ & -0.23 & $-0.283 *$ & $-0.325^{* *}$ & $-0.348 * *$ & -0.09 & -0.115 & 0.02 \\
\hline & Sig.(2-tailed) & 0.591 & 0.001 & 0.05 & 0.019 & 0.006 & 0.003 & 0.44 & 0.384 & 0.88 \\
\hline \multirow[t]{2}{*}{$\mathrm{N}$} & Pearson Correlation & 0.099 & 0.009 & 0.09 & -0.023 & -0.74 & -0.075 & 0.06 & 0.114 & 0.20 \\
\hline & Sig.(2-tailed) & 0.42 & 0.939 & 0.45 & 0.854 & 0.544 & 0.538 & 0.64 & 0.351 & 0.10 \\
\hline \multirow[t]{2}{*}{$P$} & Pearson Correlation & -0.129 & -0.105 & -0.01 & -0.002 & -0.124 & -0.106 & 0.06 & $0.489 * *$ & $0.40 * *$ \\
\hline & Sig.(2-tailed) & 0.292 & 0.389 & 0.94 & 0.989 & 0.309 & 0.386 & 0.61 & 0 & 0.001 \\
\hline \multirow[t]{2}{*}{$\mathrm{Na}$} & Pearson Correlation & -0.18 & -0.19 & 0.15 & 0.078 & -0.022 & -0.009 & 0.17 & $0.53^{* *}$ & 0.21 \\
\hline & Sig.(2-tailed) & 0.882 & 0.876 & 0.212 & 0.526 & 0.859 & 0.94 & 0.171 & 0 & 0.07 \\
\hline \multirow[t]{2}{*}{ Clay } & Pearson Correlation & -0.112 & 0.158 & -0.058 & 0.122 & 0.107 & 0.121 & 0.02 & 0.06 & -0.09 \\
\hline & Sig.(2-tailed) & 0.361 & 0.195 & 0.64 & 0.319 & 0.383 & 0.322 & 0.92 & 0.624 & 0.48 \\
\hline \multirow[t]{2}{*}{ Silt } & Pearson Correlation & -0.038 & 0.12 & -0.08 & 0.014 & 0.014 & 0.027 & $0.31 *$ & 0.017 & 0.05 \\
\hline & Sig.(2-tailed) & 0.755 & 0.325 & 0.50 & 0.912 & 0.911 & 0.823 & 0.01 & 0.888 & 0.69 \\
\hline \multirow[t]{2}{*}{ Sand } & Pearson Correlation & 0.109 & -0.19 & 0.09 & -0.1 & -0.089 & -0.108 & -0.18 & -0.055 & 0.04 \\
\hline & Sig.(2-tailed) & 0.372 & 0.117 & 0.45 & 0.412 & 0.467 & 0.375 & 0.12 & 0.651 & 0.75 \\
\hline \multirow[t]{2}{*}{$\mathrm{Ca}$} & Pearson Correlation & -0.041 & -0.022 & 0.03 & 0.038 & 0.129 & 0.022 & -0.20 & $0.325^{* *}$ & 0.06 \\
\hline & Sig.(2-tailed) & 0.74 & 0.86 & 0.80 & 0.756 & 0.292 & 0.86 & 0.98 & 0.006 & 0.62 \\
\hline \multirow[t]{2}{*}{$\mathrm{Mg}$} & Pearson Correlation & -0.038 & $0.382 * *$ & 0.17 & $0.322^{* *}$ & $0.584^{* *}$ & $0.423 * *$ & -0.19 & -0.075 & -0.04 \\
\hline & Sig.(2-tailed) & 0.758 & 0.001 & 0.16 & 0.007 & 0 & 0 & 0.11 & 0.539 & 0.75 \\
\hline \multirow[t]{2}{*}{$\mathrm{E}$} & Pearson Correlation & 0.013 & $0.317 * *$ & 0.15 & $0.244^{*}$ & $0.301^{*}$ & $0.331 * *$ & $0.279 *$ & -0.147 & -0.03 \\
\hline & Sig.(2-tailed) & 0.917 & 0.008 & 0.23 & 0.043 & 0.012 & 0.005 & 0.02 & 0.229 & 0.80 \\
\hline \multirow[t]{2}{*}{ S } & Pearson Correlation & $-0.268 *$ & $0.299 *$ & 0.05 & 0.162 & $0.384 * *$ & $0.27 *$ & -0.11 & -0.061 & -0.18 \\
\hline & Sig.(2-tailed) & 0.026 & 0.012 & 0.67 & 0.183 & 0.001 & 0.025 & 0.38 & 0.621 & 0.16 \\
\hline \multirow[t]{2}{*}{ As } & Pearson Correlation & -0.195 & 0.112 & 0.01 & 0.062 & 0.069 & 0.054 & -0.16 & 0.124 & -0.07 \\
\hline & Sig.(2-tailed) & 0.108 & 0.361 & 0.92 & 0.61 & 0.572 & 0.662 & 0.199 & 0.311 & 0.57 \\
\hline
\end{tabular}

**Correlation is significant at the 0.01 level (2-tailed)

*Correlation is significant at the 0.05 level (2-tailed) 
was detected between the silt and sand percent and $\mathrm{pH}$, soluble potassium and total nitrogen (Table 1). Although, soluble phosphorous showed a sole positive correlation with soluble sodium (at 0.01 level), slope factor is greatly affected by soluble potassium and Magnesium (at 0.01 level) (Table 1). Table 2 shows that soluble Magnesium has a positive correlation with Viola odorata, Sanicula europea, Tamus communis, Cruciata taurica. Epimedium pinnatum, Cruciata taurica, Fragaria vesca and a sole correlation were reported between slop factor and Carex digidata (Table 2).

\section{CONCLUSION}

Identification of the homogeneity throughout the site is of high applicability in variable sciences in order to simplify the further studies (Pourhashemi et al., 2004). Analysis of plant coverage, as well as identification of ecological groups is the most suitable and accurate method in site classification. Since, plants are considered as the most appropriate definer and factor in the classification of the site, determine of homogenous groups of species is of high accuracy (Spies and Barnes, 1997). Moreover, soil properties play a crucial role in this purpose (Archambault et al., 1989; Niepolla, 1993). The aforementioned classifications can be also applied to the samplings in soil studies, as well as investigation of the relation of ecologic variables (Pourhashemi et al., 2004). Correlation results showed that Sanicula europea, Tamus communis, Cruciata taurica, Epimedium pinnatum and Fragaria vesca had a key correlation with $\mathrm{pH}$ of soil. However, Cephalantera longifolia and Oplismenus undulatifolius showed a correlation with $\mathrm{Na}, \mathrm{P}$ and $\mathrm{Ca}$ and phosphorous, respectively. Zas and Alonso (2002) reported that D.cantabrica and Erica sp. is correlated with $\mathrm{pH}$ of soil; L.postrata and $D$. cantabrica species with low amount of soluble phosphorous (P) and Erica sp. with low amount of soluble $\mathrm{Ca}$ and $\mathrm{Mg}$. the presence of these species is highly affected by the aforementioned soil parameters respectively. Aubert (1987); Carlile and Bedford (1988); Harig (1987) proved a correlation between the Erica sp. with high amount of $\mathrm{pH}$ and $\mathrm{Ca}$. Canonical correspondence analysis showed that silt percent, organic matter, soluble phosphorous and potassium are among the crucial edaphic factors. Ruggiero et al. (2002) demonstrated that clay and silt percent, $\mathrm{pH}, \mathrm{K}$ and aluminium play a key role in the establishment of some of the plant species in Brazilian forests. Heydari et al. (2009) reported that organic matter, $\mathrm{pH}$, total $\mathrm{N}$, silt percent and saturated moisture are among the important factors in distribution of the species throughout the western Iran. However, Eshaghi-Rad et al. (2009) found that clay percent, total $\mathrm{N}$, phosphorous, OM and commutative cations are as important elements in distribution of species in the forest of northern Iran. Results showed that among the physiographic factors (slope, orientation and elevation), the first two are the most important ones in the establishment of Hedera pastuchowii, Solanum kieseritzkii and Saxifraga cymbalaria. According to Heydari et al. (2009), elevation factor is highly effective in establishment of Galium verum and Bromus tectorum. Baruch (2005) and McNab et al. (1999) identified elevation as the most important factor. Each species has a relation with the ecological and physiographic conditions and soil properties, therefore, the obtained results are applicable just in the similar regions. Using multivariate analysis and also due to the high accuracy of the mentioned methods in analysis of the effects of environmental factors on the plant coverage, understanding of the complex relations between the species and the environment become easier. Eventually, environmental factors including slope, orientation, silt percent, acidity, organic material, soluble phosphorous were among the most effective factors in establishment of Hedera pastuchowii, Solanum kieseritzkii, Oplismenus undulatifolius, Sedum stoloniferum, Rubus hyrcanus and Saxifraga cymbalaria species.

\section{ACKNOWLEDGEMENTS}

The authors thank the Islamic Azad University, Science and Research Branch for providing financial support for this project.

\section{REFERENCES}

Archambault, L.; Barnes, B. V.; Witter, J. A., (1989). Ecological species groups of oak ecosystem of southeastern Michigan. Forest Sci., 35 (4), 1058-1074 (17 pages).

Aubert, G., (1978). Relations entre le sol et cinq especes d'ericacees dans le sud-est de la France. Oecol. Plant., 13, 253-369 (17 pages).

Augusto, L.; Dupouey, J. L.; Ranger, J., (2003). Effects of tree species on understory vegetation and environmental conditions in temperate forests. Ann. Forest Sci., 60 (8), 823-831 (9 pages). 
Baruch, Z., (2005). Vegetation-environment relationships and classification of the seasonal savannas in Veneuela. Flora., 200 (1), 49-64 (16 pages).

Bernhardt-Römermann, M.; Kudernatsch, T.; Pfadenhauer, J.; Kirchner, M.; Jakobi, G.;Fischer, A., (2007). Long-term effects of nitrogen-deposition on vegetation in a deciduous forest near Munich, Germany. Appl. Veg. Sci., 10 (3), 399406 (8 pages).

Braun-Blanquet, J., (1932). Plant sociology. The study of plant communities. McGraw-Hill book company, Inc. New York and London.

Carlile, W. R.; Bedford, I., (1988). Plant growth in container media amended with calcined clay. Acta Hort., 221, 117132 (16 pages).

Coll, L.; Balandier, P.; Picon-Cochard, C.; Prevosto, B.; Curt, T., (2003). Competition for water between beech seedlings and surrounding vegetation in different light and vegetation composition conditions. Ann. Forest Sci., 60 (7), 593600 (8 pages)

Daubenmire, R. F., (1976). The use of vegetation in assessing the productivity of forest lands. Botan. Rev., 42 (2), 115143 (29 pages).

Ellenberg, H.; Weber, H. E.; Dull, R., (1992). Zeigerwerte von Pflanzen in Mitteleuropa. Verlag Erich Goltze KG.

Eshaghi-Rad, J.; Manthey, M.; Mataji, A., (2009). Comparison of plant species diversity with different plant communities in deciduous forests. Int. J. Environ. Sci. Tech., 6 (3), 389-394 (6 pages)

Eshaghi-Rad, J.; Zahedi Amiri, Gh.; Mataji, A., (2009). Determination of optimum number of ecological groups in vegetation classification case study Kheiroudkenar forests. Iran. J. Forest Poplar Res., 16 (3), 455-466 (11 pages)

Eshaghi-Rad, J.; Zahedi Amiri, Gh.; Marvi Mohajer, M. R.; Mataji, A.,(2009). Relationship between vegetation and physical and chemical properties of soil in Fagetum communities. Iran. J. Forest Poplar Res., 17 (2), 174-187 (14 pages).

Fu, B. J.; Liu, S. L.; Ma, K. M.; Zhu, Y. G., (2004). Relationships between soil characteristics, topography and plant diversity in a heterogeneous deciduous broadleaved forest near Beijing, China. Plant Soil., 261 (1-2), 47-54 (8 pages).

Gueu, S.; Yao, B.; Adouby, K.; Ado, G., (2007). Kinetics and thermodynamics study of lead adsorption on to activated carbons from coconut and seed hull of the palm tree. Int. J. Environ. Sci. Tech. 4 (1), 11-17 (6 pages).

Harig, R., (1987). Clay or plastic pots for ericas? Deutscher Gartenbau., 41, 110-112 (3 pages).

Hassani Pak, A. A.; Sharafodin, M., (2005). Expoloration data analysis. Tehran University Press.

Hassanzad Navroodi, I.; Namiranian, M.; Zahedi Amiri, Gh., (2004). An evaluation of relationship between quantitative and qualitative characteristics and site factors in the natural Beech (Fagus orientalis) stands in Asalem. Iranian J. Natur. Resour., 57 (2), 235-247 (13 pages).

Heydari, M.; Mahdavi, A.; Ata-Roshan, S., (2009). Identification of relationship between some physiographic attributes and physico-chemical soil properties and ecological groupes in Melehgavan protected area, Ilam. Iran. J. Forest Poplar Res., 17 (1), 149-160 (12 pages).
Hill, M. O., Gauch, H. G., (1980). Detrended correspondence analysis: An improved ordination technique. Plant Eco., 42 (1-3), 47-58 (12 pages).

Igwe, J. Ch.; Abia, A. A.; Ibe, Ch. A., (2008). Adsorption kinetics and intraparticulate diffusivities. Int. J. Environ. Sci. Tech., 5 (1), 83-92 (10 pages).

Karimzadegan, H.; Rahmatian, M.; Dehghani Salmasi, M.; Jalali, R.; Shahkarami, A., (2007). Valuing forests and rangelandsecosystem services. Int. J. Environ. Res., 1 (4), 368-377 (10 pages).

Kord, B.; Mataji, A.; Babaie, S., (2010). Pine (Pinus Eldarica Medw.) needles as indicator for heavy metals pollution. Int. J. Environ. Sci. Tech., 7 (1), 79-84 (6 pages).

Lepetu, J.; Alavalapati, J.; Nair, P. K., (2009). Forest Dependency and Its Implication for Protected Areas Management: A case Study From Kasane Forest Reserve, Botswana. Int. J. Environ. Res. 3 (4), 525-536 (12 pages).

Mahmood, A.; Athar, M. (2008). Cross inoculation studies: Response of Vigna mungo to inoculation with rhizobia from tree legumes growing under arid Environment. Int. J. Environ. Sci. Tech., 5 (1), 135-139 (5 pages).

Mataji, A.; Zahedi Amiri, Gh.; Asri,Y., (2009). Vegetation analysis based on plant associations and soil properties in natural forests. Iran. J. Forest Poplar Res., 17 (1), 85-98 (14 pages).

Mataji, A.; Zahedi Amiri, Gh.; Sagheb Talebi, Kh.; Asri, Y., (2007). Site classification based on plant associations in natural forests. J. Iran. Natur. Res., 60, 517-536 (20 pages).

McCune, B.; Mefford, M. J., (1999). PC-ORD for windows (software). Multivariate analysis of ecological data. Version 4.14. MjM Software, Gleneden Beach, OR, USA.

McNab, W. H.; Browning, S. A.; Simon, S. A.; Fouts, P. E., (1999). An unconventional approach to ecosystem unit classification in western north Carolina. Forest Eco. Manag., 114 (2-3), 405-420 (16 pages).

Meilleur, A.; Bergeron, Y., (1992). The use of understory species as indicators of landform ecosystem type in heavily disturbed forests: An evaluation in the Haut-SaintLaurent, Quebec. Vegetation., 102 (1), 13-32 (20 pages). Mölder, A.; Bernhardt-Römermann, M.; Schmidt, W., (2006). Forest ecosystem research in Hainich National Park (Thuringia): First results on flora and vegetation in stands with contrasting tree species diversity. Waldökologie-Online. 3, 83-99 (17 pages).

Mölder, A.; Bernhardt-Romermann, M.; Schmidt, W., (2008). Herb-layer diversity in deciduous forests: Raised by tree richness or beaten by beech? Forest Eco. Manag., 256 (3), 272-281 (10 pages).

Morris, L. A.; Moss, S. A.; Garbett, W. S., (1993). Competitive interference between selected herbaceous and woody plants and Pinus taeda L. during two growing seasons following planting. Forest Sci., 39 (1), 166-187 (21 pages).

Naqinezhad, A.; Hamzehee, B.; Attar, F., (2008). Vegetationenvironment relationships in the alderwood communities of Caspian lowlands, N.Iran (toward an ecological classification). Flora, 203 (7), $567-577$ (11 pages).

Nieppola, J., (1993). Understorey plants as indicators of site productivity in Pinus sylvestris L. stands. Scand. J. 
Forest Res., 8 (1-4), 49-65 (17 pages)

Pinto, J. R. R.; Oliveira-Filho, A. T.; Hay, J. D. V., (2006). Influence of soil and topography on the composition of a tree community in a centeral Brazilian valley forest. Edinburgh J. Bot., 62 (1-2), 69-90 (22 pages).

Pourhashemi, M.; Marvi Mohajer, M. R.; Zobeiri, M.; Zahedi Amiri, Gh., (2004). Site classifying using plant cover analysis in Oak coppice forests of Marivan. Iran. J. Natur. Resour., 56 (1), 97-108 (12 pages).

Ramirez, N.; Dezzeo, N.; Chacon, N., (2007). Flroristic composition, plant species abundance, and soil properties of montane savannas in the Gran Sabana, Venezuela. Flora., 202 (4), 316-327 (12 pages)

Ruggiero P. G.; Batalha M. A.; Pivello V. R.; Meirelles S. T., (2002). Soil-Vegetation relationships in cerrado (Brazilian savanna) and semideciduous forests, Southeastern Brazil. Plant Eco., 160 (1), 1-16 (16 pages).

Samghabodi, A.; Amani, M.; Memariani, A., (2004). Silvicultural operations in the Caspian low land regions of Iran.

Pajouhesh-va-Sazandegi., 63 (2), 23-34 (12 pages).
Schmidt, W., (2005). Herb layer species as indicators of biodiversity of managed and unmanaged beech forests. For. Snow Landsc. Res., 79 (1-2), 111-125 (15 pages).

Spies, T. A.; Barnes, B. V., (1985). A multifactor ecological classification of the northern hardwood and conifer ecosystems of Sylvania recreaction area, upper Peninsula, Michigan. Can. J. Forest Res., 15 (5), 949-960 (12 pages).

Ter Braak, C. J. F., (1986). Canonical correspondence analysis: A new eigenvector method for multivariate direct gradient analysis. Ecology, 67 (5), 1167-1179 (13 pages).

Zahedi Amiri, Gh.; Mohammadi Limayi, S., (2002). Relationship between plant ecological groups in herbal layer and forest stand factors. Iran. J. Natur. Res., 55 (3), 341353 (13 pages)

Zas, R.; Alonso, M., (2002). Understory vegetation as indicators of soil characteristics in northern Spain. Forest Eco. Manag., 171 (1-2), 101-111 (11 pages).

Zhang, J.; Dong, Y.; Xi, Y., (2008). A comparison of SOFM ordination with DCA and PCA in gradient analysis of plant communities in the midst of Taihang mountains, China. Ecol. Info., 3 (6), 367-374 (8 pages).

\section{AUTHOR (S) BIOSKETCHES}

Mataji, A., Associate Professor, Department of Forestry, Science and Research Branch, Islamic Azad University, Tehran, Iran. P.O.Box 14515-775, Tehran, Iran. Email: amataji@srbiau.ac.ir

Moarefvand, P., . Assistant Professor, Department of Mining and Metallurgy Engineering, Amirkabir University of Tehran, Iran. P.O.Box 242 Hafez Ave, Tehran, Iran. Email: parviz_moaref@yahoo.fr

Babaie Kafaki, S., Assistant Professor, Department of Forestry, Science and Research Branch, Islamic Azad University, Tehran, Iran. P.O.Box 14515-775, Tehran, Iran. Email: babaei47@yahoo.com

Madanipour Kermanshahi, M., Ph.D Candidate, Department of Forestry, Science and Research Branch, Islamic Azad University, Tehran, Iran. P.O.Box 14515-775, Tehran, Iran. Email: fmmk_lk@yahoo.com

How to cite this article: (Harvard style)

Mataji, A.; Moarefvand, P.; Babaie Kafaki, S.; Madanipour Kermanshahi, M., (2010). Understory vegetation as environmental factors indicator in forest ecosystems. Int. J. Environ. Sci. Tech., 7 (4), 629-638. 